\title{
Karyotype and nuclear DNA content of Trichomycterus areolatus (Siluriformes, Trichomycteridae)
}

\author{
Nelson Colihueque, Olga Corrales and Margarita Parraguez \\ Universidad de Los Lagos, Departamento de Ciencias Básicas, Laboratorio de Genética y Acuicultura, \\ Osorno, Chile
}

\begin{abstract}
Cytogenetic analysis of Trichomycterus areolatus, collected from the Tijeral and Huilma Rivers in southern Chile has shown a diploid chromosome number of $2 n=54$, a fundamental number of $F N=106$, and a karyotypic formula of $44 m+8 s m+2 s t$. Intra-individual polymorphism of chromosome number $(2 n=54,55$ and 56$)$ in specimens from the Huilma River has also been documented, providing further evidence of the occurrence of this phenomenon in Trichomycterus. The karyotype exhibited large chromosome pairs: metacentric pairs 1 (relative length $7.54 \%$ ), 2 $(5.75 \%)$ and $3(5.09 \%)$, submetacentric pair $23(5.25 \%)$, and subtelocentic pair 27 (5.28\%). Nuclear DNA content analysis showed an average value of $5.04 \pm 1.09 \mathrm{pg} /$ nucleus. This DNA content is higher than the mean value described for other species in this genus.
\end{abstract}

Key words: karyotype, nuclear DNA content, Trichomycterus, Siluriformes.

Received: December 23, 2004; Accepted: October 10, 2005.

Trichomycterus areolatus is a small native catfish ( $<10 \mathrm{~cm}$ length) that inhabits the Andean river basins in Chile (Arratia, 1981; Vila et al., 1999). This species belongs to the family Trichomycteridae, which is native to southern Central America and South America (Berra, 1990) and comprises nine sub-families, 37 genera and 156 species (Nelson, 1994). The subfamily Trichomycterinae includes six genera: Bullockia, Eremophilus, Hatcheria, Rhizosomichthys, Scleronema and Trichomycterus (Nelson, 1994), the latter being the most diversified, possibly with more than 75 species, widely distributed throughout South America, from the Atlantic coast to the Pacific. Chromosome data obtained for the genus Trichomycterus from various species distributed in Brazil and Argentina show that this group has a constant diploid chromosome number $(2 \mathrm{n}=54)$, but the number of chromosome arms or fundamental number $(\mathrm{FN})$ varies $(\mathrm{FN}=84,104,106$ or 108) (Torres et al., 1998; Borin and Martins-Santos, 1999; Gonzo et al., 2000; Sato et al., 2004). In Chile, T. areolatus presents different diploid chromosome numbers: $2 \mathrm{n}=54$ (Arratia and Veloso, 1980) and 2n $=56$ (Arratia and Campos, 1997). In this study, we present data on various cytogenetic parameters (diploid chromosome number, fundamental number, chromosome size, chromosome formula and nuclear DNA content) in two populations of $T$.

Send correspondence to N. Colihueque. Universidad de Los Lagos, Departamento de Ciencias Básicas, P.O. Box 933, Osorno, Chile. E-mail: ncolih@ulagos.cl. areolatus that inhabit southern Chile. This analysis provides further information that contributes to our understanding of the evolutionary process that occurred in this species of the Trichomycteridae family.

The specimens studied were collected from the Tijeral and Huilma Rivers, in the south of Chile (Bueno River hydrographic basin, Province of Osorno, $10^{\text {th }}$ Region). Chromosome preparations were obtained by the squash method from bronchial epithelium of the fishes, previously treated with an intraperitoneal colchicine injection $(0.5 \%$ $\mathrm{p} / \mathrm{v}$ ). Thirteen individuals from the Tijeral River (two males, two females and nine of unknown sex) and twelve from the Huilma River (two males, two females and eight of unknown sex) were analyzed. The chromosomes were stained with $4 \%$ Giemsa solution. Chromosome morphology was identified based on the centromeric index, following the protocol of Levan et al. (1964). For the fundamental number determinations, it was assumed that metacentric and submetacentric chromosomes are two-armed chromosomes, and the subtelocentric and telocentric (= acrocentric) are one-armed chromosomes. The length of the short arm (SA) and long arm (LA) of each chromosome pair of the karyotype was obtained, and the absolute values were standardized as relative lengths over the total length of the haploid chromosome complement. For each chromosome pair, the total relative length (TRL) in percentage and the total absolute length (TAL) in $\mu \mathrm{m}$ were also recorded. The nuclear DNA content of $T$. areolatus was determined by 
microdensitometry, using Feulgen-stained nuclei of erythrocytes. For this analysis, quantification of the nuclear DNA content involved the use of chicken Feulgen-stained nuclei erythrocytes as a standard, which were used to transform the relative values of each nucleus measurement into absolute values in DNA picograms (pg), using the value established for this species $(2.49 \mathrm{pg} /$ nucleus, according to Johnston et al., 1999). Ten individuals were used for this analysis.

Both the Tijeral and the Huilma River samples had a modal diploid chromosome number of $2 n=54$. The distribution of cells from specimens collected in the River Tijeral was as follows: two had 50 chromosomes, one had 51 chromosomes, seven had 52 chromosomes, 48 had 54 chromosomes, three had 55 chromosomes, and two had 56 chromosomes. The distribution of cells from specimens collected in the Huilma River was: six cells had 50 chromo- somes, 12 had 51 chromosomes, nine had 52 chromosomes, two had 53 chromosomes, 62 had 54 chromosomes, 15 had 55 chromosomes, and 25 had 56 chromosomes. Thus, $76.2 \%(48 / 63)$ and $50.8 \%(62 / 122)$ of the metaphase plates studied had a modal diploid number of 54 chromosomes, in the samples from the Tijeral and the Huilma Rivers, respectively. The chromosome formula, based on centromeric index values, showed that in both populations the karyotype consisted of $44 \mathrm{~m}+8 \mathrm{sm}+2 \mathrm{st}$, with a fundamental number of FN $=106$ (Table 1). The chromosome pairs with the largest TRL were metacentric pairs 1 (7.54\%), 2 (5.75\%), and 3 (5.09\%); submetacentric pair 23 (5.25\%), and subtelocentric pair 27 (5.28\%) (Table 1). These pairs were easily identified in the karyotype (Figure 1a).

The diploid number of $2 \mathrm{n}=54$ that we observed in $T$. areolatus was also described by Arratia and Veloso (1980), but differs from another chromosome analysis which re-

Table 1 - Values of karyotype parameters in T. areolatus $(2 n=54)(n=9$ chromosome metaphase plates): average relative length in percentage of short arm (SA) and long arm (LA) of each chromosome pair are shown; total relative length (TRL) and total absolute length (TAL) of each chromosome pair are also shown. The chromosome types were classified according to the centromeric index $(\mathrm{CI})$. SD = standard deviation.

\begin{tabular}{|c|c|c|c|c|c|c|}
\hline \multirow[t]{2}{*}{ Chromosome pair } & SA & LA & \multirow[b]{2}{*}{$\mathrm{CI} \pm \mathrm{SD}$} & \multirow[b]{2}{*}{$\mathrm{TRL} \pm \mathrm{SD}(\%)$} & \multirow[b]{2}{*}{$\mathrm{TAL} \pm \mathrm{SD}(\mu \mathrm{m})$} & \multirow[b]{2}{*}{ Chromosome type } \\
\hline & $\mathrm{Av} \pm \mathrm{SD}$ & $\mathrm{Av} \pm \mathrm{SD}$ & & & & \\
\hline 1 & $3.13 \pm 0.48$ & $4.41 \pm 0.88$ & $41.23 \pm 2.09$ & $7.54 \pm 1.33$ & $2.11 \pm 0.88$ & $\mathrm{~m}$ \\
\hline 2 & $2.56 \pm 0.49$ & $3.19 \pm 0.34$ & $43.86 \pm 2.65$ & $5.75 \pm 0.79$ & $1.60 \pm 0.62$ & $\mathrm{~m}$ \\
\hline 3 & $2.31 \pm 0.28$ & $2.78 \pm 0.33$ & $44.93 \pm 2.41$ & $5.09 \pm 0.50$ & $1.39 \pm 0.44$ & $\mathrm{~m}$ \\
\hline 4 & $2.15 \pm 0.15$ & $2.60 \pm 0.27$ & $45.21 \pm 3.04$ & $4.75 \pm 0.29$ & $1.30 \pm 0.37$ & $\mathrm{~m}$ \\
\hline 5 & $2.01 \pm 0.22$ & $2.45 \pm 0.11$ & $44.40 \pm 2.24$ & $4.46 \pm 0.23$ & $1.20 \pm 0.33$ & $\mathrm{~m}$ \\
\hline 6 & $1.89 \pm 0.24$ & $2.30 \pm 0.13$ & $44.21 \pm 2.49$ & $4.19 \pm 0.27$ & $1.12 \pm 0.30$ & $\mathrm{~m}$ \\
\hline 7 & $1.75 \pm 0.25$ & $2.17 \pm 0.16$ & $44.29 \pm 4.13$ & $3.92 \pm 0.29$ & $1.16 \pm 0.28$ & $\mathrm{~m}$ \\
\hline 8 & $1.75 \pm 0.21$ & $2.08 \pm 0.16$ & $45.24 \pm 2.47$ & $3.83 \pm 0.32$ & $1.03 \pm 0.25$ & $\mathrm{~m}$ \\
\hline 9 & $1.65 \pm 0.17$ & $2.03 \pm 0.12$ & $44.33 \pm 1.41$ & $3.68 \pm 0.24$ & $0.99 \pm 0.24$ & $\mathrm{~m}$ \\
\hline 10 & $1.62 \pm 0.15$ & $1.96 \pm 0.14$ & $44.72 \pm 2.36$ & $3.59 \pm 0.17$ & $0.97 \pm 0.24$ & $\mathrm{~m}$ \\
\hline 11 & $1.64 \pm 0.14$ & $1.86 \pm 0.12$ & $46.40 \pm 2.05$ & $3.50 \pm 0.19$ & $0.94 \pm 0.23$ & $\mathrm{~m}$ \\
\hline 12 & $1.51 \pm 0.13$ & $1.83 \pm 0.12$ & $45.11 \pm 2.44$ & $3.34 \pm 0.17$ & $0.90 \pm 0.22$ & $\mathrm{~m}$ \\
\hline 13 & $1.48 \pm 0.14$ & $1.75 \pm 0.12$ & $45.63 \pm 2.04$ & $3.23 \pm 0.20$ & $0.87 \pm 0.20$ & $\mathrm{~m}$ \\
\hline 14 & $1.39 \pm 0.22$ & $1.73 \pm 0.14$ & $43.38 \pm 1.67$ & $3.13 \pm 0.24$ & $0.83 \pm 0.20$ & $\mathrm{~m}$ \\
\hline 15 & $1.43 \pm 0.17$ & $1.62 \pm 0.17$ & $46.37 \pm 3.34$ & $3.05 \pm 0.21$ & $0.81 \pm 0.18$ & $\mathrm{~m}$ \\
\hline 16 & $1.35 \pm 0.16$ & $1.56 \pm 0.16$ & $46.17 \pm 3.22$ & $2.90 \pm 0.22$ & $0.78 \pm 0.17$ & $\mathrm{~m}$ \\
\hline 17 & $1.29 \pm 0.17$ & $1.49 \pm 0.10$ & $46.16 \pm 2.41$ & $2.78 \pm 0.24$ & $0.74 \pm 0.16$ & $\mathrm{~m}$ \\
\hline 18 & $1.21 \pm 0.20$ & $1.46 \pm 0.14$ & $44.86 \pm 3.31$ & $2.67 \pm 0.27$ & $0.71 \pm 0.15$ & $\mathrm{~m}$ \\
\hline 19 & $1.19 \pm 0.17$ & $1.34 \pm 0.14$ & $46.66 \pm 1.34$ & $2.53 \pm 0.28$ & $0.67 \pm 0.16$ & $\mathrm{~m}$ \\
\hline 20 & $1.11 \pm 0.22$ & $1.28 \pm 0.16$ & $45.85 \pm 3.87$ & $2.39 \pm 0.34$ & $0.64 \pm 0.16$ & $\mathrm{~m}$ \\
\hline 21 & $1.05 \pm 0.12$ & $1.28 \pm 0.13$ & $45.11 \pm 3.85$ & $2.32 \pm 0.18$ & $0.63 \pm 0.15$ & $\mathrm{~m}$ \\
\hline 22 & $1.13 \pm 0.37$ & $1.50 \pm 0.80$ & $44.00 \pm 4.53$ & $2.63 \pm 1.17$ & $0.71 \pm 0.35$ & $\mathrm{~m}$ \\
\hline 23 & $2.00 \pm 1.19$ & $3.25 \pm 0.90$ & $35.12 \pm 2.19$ & $5.25 \pm 1.34$ & $1.35 \pm 0.49$ & $\mathrm{sm}$ \\
\hline 24 & $1.34 \pm 0.45$ & $2.51 \pm 0.45$ & $32.45 \pm 3.89$ & $3.85 \pm 0.72$ & $1.05 \pm 0.46$ & $\mathrm{sm}$ \\
\hline 25 & $1.15 \pm 0.38$ & $1.97 \pm 0.18$ & $34.22 \pm 3.47$ & $3.12 \pm 0.31$ & $0.83 \pm 0.29$ & $\mathrm{sm}$ \\
\hline 26 & $0.95 \pm 0.26$ & $1.72 \pm 0.32$ & $33.98 \pm 5.37$ & $2.67 \pm 0.32$ & $0.71 \pm 0.22$ & $\mathrm{sm}$ \\
\hline 27 & $1.55 \pm 0.76$ & $3.73 \pm 1.24$ & $26.19 \pm 1.82$ & $5.28 \pm 1.63$ & $1.43 \pm 0.75$ & st \\
\hline
\end{tabular}




\section{a)}

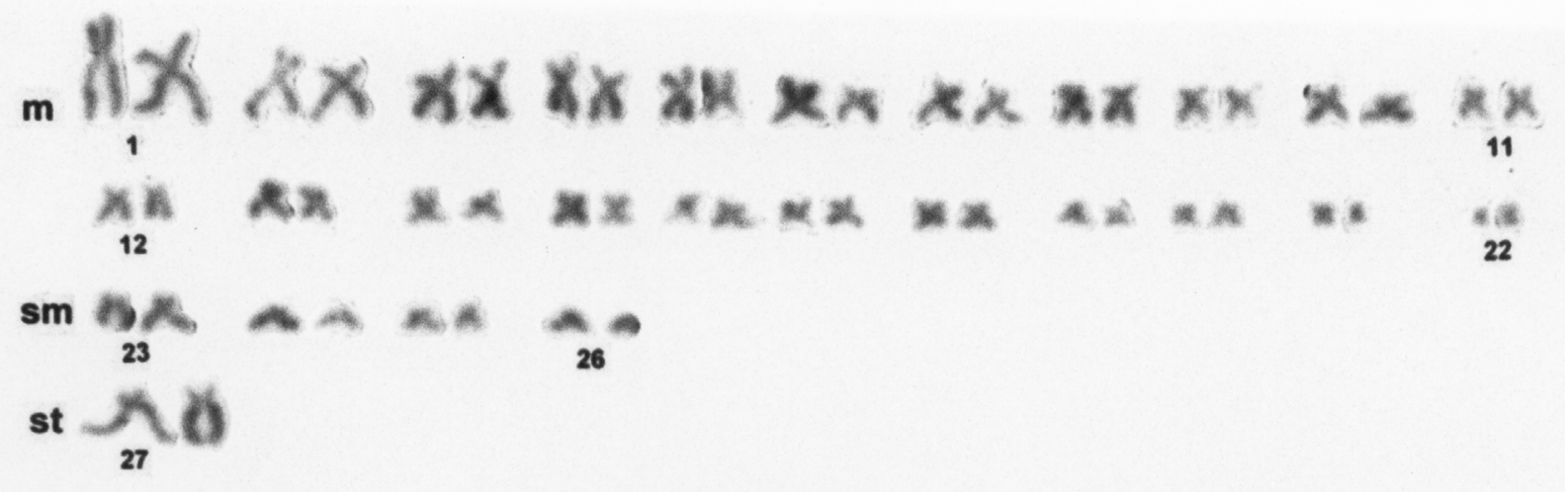

b)
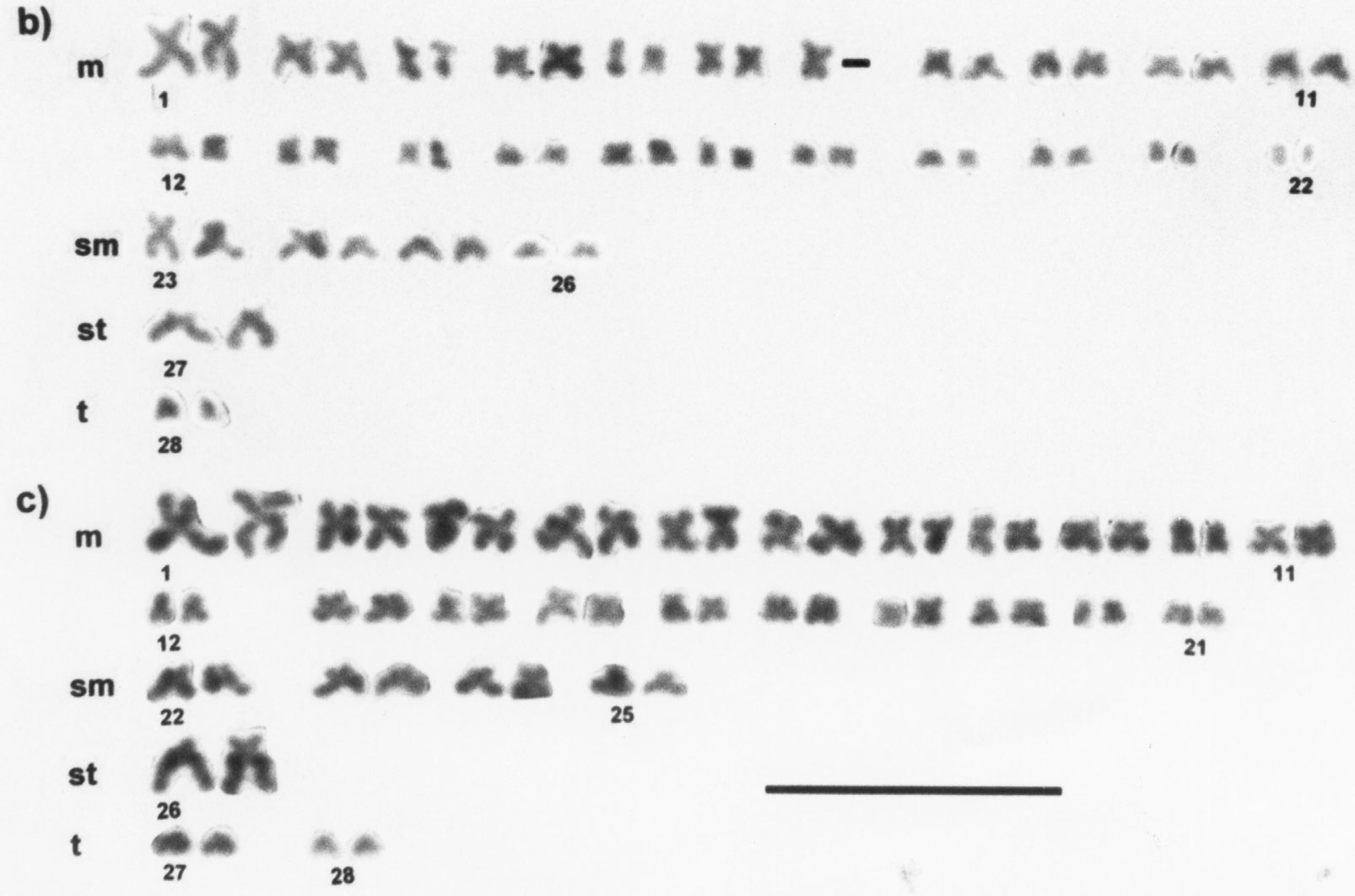

Figure 1 - Karyotypes of $T$. areolatus from Chile. a) Karyotype with $2 \mathrm{n}=54$ chromosomes of the Tijeral and Huilma River populations. In b) and c) karyotypes with $2 \mathrm{n}=55$ and $2 \mathrm{n}=56$ chromosomes, respectively, representing the intra-individual numerical chromosome variation observed in some specimens of the Huilma River. Chromosome morphologies: $\mathrm{m}=$ metacentric, $\mathrm{sm}=$ submetcentic, $\mathrm{st}=$ subtelocentric, and $\mathrm{t}=$ telocentric $(=$ acrocentric $)$. Bar represents $5 \mu \mathrm{m}$.

ported $2 \mathrm{n}=56$ (Arratia and Campos, 1997). These data indicate the occurrence of intraspecific polymorphism for diploid chromosome number in Chilean $T$. areolatus. Further studies are necessary to determine the extent of this type of chromosome variation.

The $2 \mathrm{n}=54$ diploid number here described in $T$. areolatus has been reported in most of the Trichomycterus species (Torres et al., 1998; Borin and Martins-Santos, 1999; Gonzo et al., 2000; Sato et al., 2004). Therefore, this diploid number appears to be conserved within the genus. However, not all the Trichomycterus species with $2 \mathrm{n}=54$ have the same chromosome formula. This becomes apparent by comparing $T$. areolatus $[44 \mathrm{~m}+8 \mathrm{sm}+2 \mathrm{st}]$ (this study) with $T$. paolence $[46 \mathrm{~m}+6 \mathrm{sm}+2 \mathrm{st}]$ (Torres et al., 1998), T. Stawiarski $[42 \mathrm{~m}+8 \mathrm{sm}+4 \mathrm{st}]$ (Borin and Martins-Santos, 1999) and T. davisi [42m $+10 \mathrm{sm}+2 \mathrm{st}]$ (Sato et al., 2004). These interspecific chromosome differences suggest that structural rearragements must have occurred during the chromosomal evolution of these species.

Sato et al. (2004) grouped the cis-Andean Trichomycterys species into two groups, according to the size of the first metacentric chromosome pairs and the loca- 
tion of NORs. In group 1, the first metacentric pair was considerably larger than the second, and the Ag-NOR was located in a pericentromeric position on the short arm of a large submetacentric pair. In group 2, the first and second metacentric pairs were similar in size and larger than the other metacentrics; the NOR was pericentromeric, but located on the long arm of a large metacentric pair. Our data on relative chromosome sizes (Table 1) would place $T$. areolatus in the first group, since its first metacentric pair is larger than the second metacentric pair (TRL $7.54 \%$ vs. $5.75 \%$ ). However, our preliminary unpublished data show that Ag-NOR location in this species is similar to that observed in group 2. This suggests that in Chile T. areolatus has particular cytogenetic characteristics, in line with the great chromosomal variability observed in other Chilean species of Trichomycterus, such as T. chiltoni $[2 \mathrm{n}=52]$ and T. laucaensis [ $2 \mathrm{n}=62]$ (Arratia and Campos, 1997), and with a distinctive phylogenetic branch within Trichomycteridae, according to Wosiacki (2002).

Oliveira and Gosztonyi (2000) proposed that the ancestral karyotype of Siluriformes had $2 n=56$. Based on the cytogenetic information available on Ictaluridae at the time, LeGrande (1981) proposed a basal $2 \mathrm{n}=58$ karyotype and a FN $>80$ for this group. The $2 \mathrm{n}=54$ and $\mathrm{FN}=106$ found in T. areolatus suggest that the karyotype of this species has primitive characteristics. This is further supported by the karyotypic characteristics of the most primitive trichomycterid species karyotyped to date, Trichogenes longipinis, with $2 \mathrm{n}=54$ and a high fundamental number $(\mathrm{FN}=102)($ Lima and Galetti Jr., 1990).

In the sample of 12 individuals from the Huilma River, four specimens studied had chromosome metaphase plates with a high frequency of 54 (44.4\%), 55 (19.5\%) and $56(23.85 \%)$ chromosomes, and NF values of about 106. The increased chromosome number, from 54 to 56 within the same individual, involved the gain of two small acrocentric pairs and the loss of a pair of metacentrics (Figure 1 $\mathrm{b}, \mathrm{c})$. Intra-individual chromosome polymorphism has also been described in other species of the genus Trichomycterus, such as T. paolence (Torres et al., 2002) and T. davisi (Borin and Martins-Santos, 2000). In T. davisi, this type of chromosome polymorphism was attributed to the occurrence of postzygotic non disjunction. In our case, the intra-individual chromosome polymorphism could have resulted from Robertsonian rearrangements (centric fusions or fissions), given that this type of rearrangement does not alter the $\mathrm{FN}$ value. This chromosome variation is not unusual in fishes, and it has been reported in various salmonid species (Hartley and Horne, 1984).

The average value of nuclear DNA content in $T$. areolatus was $5.04 \pm 1.09 \mathrm{pg} /$ nucleus (Table 2), with a coefficient of variation $(\mathrm{CV})=21.16 \%$, this variability being higher than that reported in other fishes at the intraspecific level (CV $=4 \%-6 \%$, Carvalho et al., 1998). However, if two individuals from the Tijeral River sample (n. 448 and
449, Table 2) that presented a higher value of nuclear DNA content than the others individuals (around 60\%) were not included, the average value for this parameter would be $4.54 \pm 0.44 \mathrm{pg} /$ nucleus and the coefficient of variation would be lower $(\mathrm{CV}=9.69 \%)$. In this scenario, there is no statistically significant difference between the Tijeral and Huilma River samples $(4.63 \pm 0.45 \mathrm{pg}$ /nucleus $v s$. $4.39 \pm 0.40 \mathrm{pg} /$ nucleus, $\mathrm{p}<0.05)$. This nuclear DNA content value that we found for $T$. areolatus is higher than that described in two other congeneric species that inhabit Brazil, Trichomycterus sp. (average $=2.62 \pm 0.19 \mathrm{pg} / \mathrm{nu}-$ cleus) and $T . c f$. iheringi (average $=2.3 \pm 0.23 \mathrm{pg} /$ nucleus) (Fenerich et al., 2004). These findings show that this cellular parameter varies widely in Trichomycterus. Of note are the considerable variations in nuclear DNA contents of three species of the same genus, even though they possess the same diploid number $(2 n=54)$. However, this is not atypical in fishes, given that this type of interspecific variation is often observed at the genus level (Carvalho et al., 1998; Fenerich et al., 2004), and can result from different processes, such as duplication and/or loss of chromosome segments, or differential accumulation of repeated DNA elements in the genome, as already well documented in higher vertebrates (Hartl, 2000). The nuclear DNA content

Table 2 - DNA content analysis of two populations of $T$. areolatus from Chile. DNA content was determined by microdensitometry of Feulgen-stained nuclei of erythrocytes.

\begin{tabular}{lccc}
\hline $\begin{array}{l}\text { Population/ } \\
\text { specimen } \\
\text { identification }\end{array}$ & $\begin{array}{c}\text { N. of nuclei } \\
\text { analyzed }\end{array}$ & $\begin{array}{c}\text { Average relative } \\
\text { value }\end{array}$ & $\begin{array}{c}\text { Average diploid } \\
\text { DNA content } \\
(\mathrm{pg})\end{array}$ \\
\hline $\begin{array}{l}\text { Chicken } \\
\text { Tijeral River }\end{array}$ & 200 & 31.27 & $2.49^{*}$ \\
435 & 100 & 48.99 & 4.70 \\
436 & 61 & 61.44 & 4.89 \\
437 & 57 & 54.42 & 4.33 \\
438 & 69 & 62.02 & 4.94 \\
440 & 68 & 43.19 & 4.24 \\
Average (A) & & & $4.63 \pm 0.45^{\mathrm{a} * *}$ \\
Huilma River & & & \\
444 & 71 & 51.86 & 4.13 \\
448 & 73 & 87.64 & 6.98 \\
449 & 67 & 89.00 & 7.09 \\
451 & 67 & 58.50 & 4.66 \\
452 & 64 & 55.20 & 4.40 \\
Average (B) & & & $5.47 \pm 1.37^{\mathrm{b}}$ \\
Average (C) without specimens 448 and 449 & $4.39 \pm 0.40^{\mathrm{a}}$ \\
Both populations & & & $5.04 \pm 1.09$ \\
A + B (n = 10) & & & $4.54 \pm 0.44$ \\
A + C (n = 8) & & & \\
\hline & & & \\
\hline
\end{tabular}

*Johnston et al. (1999).

**Different letters in column indicate significant difference $(\mathrm{p}<0.01)$. 
values described for Trichomycterys so far (2.3-5.04 pg/nucleus) are higher than the average described for fishes ( 2 pg/nucleus; Hinegardner and Rosen, 1972), although they fall within the upper range described for various species of Siluriformes (1.04-8.75 pg/nucleus; Carvalho et al., 1998). This high nuclear DNA content may be related to the fact that Siluriformes, as a group belonging to the superorder Ostariophysi, is a primitive group of fishes (Saitoh et al., 2003).

\section{Acknowledgments}

We are grateful to the Dirección de Investigación of the Universidad de Los Lagos, for supporting the publication of this manuscript. The collaboration of Susan Angus in the translation of the manuscript is also acknowledged.

\section{References}

Arratia G (1981) Géneros de peces de aguas continentales de Chile. Publicación Ocasional n. 34, Museo de Historia Natural, Chile.

Arratia G y Veloso A (1980) Cariotipos de peces tricomictéridos (Siluriformes). Arch Biol Med Exp 13:137 (Abstract).

Arratia G and Campos H (1997) Karyotype of diplomystid and certain loricarioid catfishes. IX International Symposium on Phylogeny and Classification of Neotropical Fishes, Porto Alegre, Rio Grande do Sul, pp 53-54.

Berra T (1990) An Atlas of Distribution of the Freshwater Fish Families of the World. University of Nebraska Press, USA, $197 \mathrm{pp}$.

Borin LA and Martins-Santos IC (1999) Karyotype characterization of the three species of the genus Trichomycterus (Teleostei, Siluriformes) from the Iguaçu river basin. Genetica 106:215-221.

Borin LA and Martins-Santos IC (2000) Intra-individual numerical chromosomal polymorphism in Trichomycterus davisi (Siluriformes, Trichomycteridae) from the Iguaçu River basin Brazil. Genet Mol Biol 23:605-607.

Carvalho M, Oliveira C and Foresti F (1998) Nuclear DNA content of thirty species of Neotropical fishes. Genet Mol Biol 21:47-54.

Fenerich PC, Foresti F and Oliveira C (2004) Nuclear DNA content in 20 species of Siluriformes (Teleostei, Ostariophysi) from the Neotropical region. Genet Mol Biol 27:350-354.

Gonzo GM, Fenocchio AS and Pastori C (2000) Chromosome characterization of Trichomycterus spegazzini (Siluriformes, Trichomycteridae) from three hydrographic basins of the northwest of Argentina. Caryologia 53:39-43.
Hartley SE and Horne MT (1984) Chromosome relationships in the genus Salmo. Chromosoma 90:229-237.

Hartl DL (2000) Molecular melodies in high and low C. Nature Rev Genet 1:145-149.

Hinegadner R and Rosen DE (1972) Cellular DNA content and evolution of teleostean fishes. Am Nat 106:621-644.

Johnston JS, Bennett MD, Rayburn AL, Galbraith, DW and Price HJ (1999) Reference standards for determination of DNA content of plant nuclei. Am J Bot 86:609-613.

LeGrande W (1981) Chromosomal evolution in north American catfishes (Siluriformes, Ictaluridae) with particular emphasis on madtoms, Noturus. Copeia 1981:33-52.

Levan A, Fredga K and Sandberg A (1964) Nomenclature for centromeric position on chromosomes. Hereditas 52:201220.

Lima NRW and Galetti Jr. PM (1990) Chromosome characterization of the fish Trichogenes longipinnis. A possible basic karyotype of Trichomycteridae. Rev Bras Genet 13:239245.

Nelson JS (1994) Fishes of the World. 3rd edition. John Wiley and Sons, New York, 416 pp.

Oliveira C, Almeida-Toledo LF, Foresti F, Britski HA and Toledo-Filho AS (1988) Chromosome formulae of Neotropical freshwater fishes. Rev Bras Genet 11:577-624.

Oliveira C and Gosztonyi AE (2000) A cytogenetic study of Diplomystes mesembrinus (Teleostei, Siluriformes, Diplomystidae) with a discussion of chromosome evolution in Siluriformes. Caryologia 53:31-37.

Torres RA, Foresti F and Oliveira C (1998) Comparative cytogenetic studies in alopatric populations of Trichomycterus paolence Eigenmann, 1918 from Southeastern Brazil (Siluriformes, Trichomycteridae). Cytologia 63:107-114.

Torres RA, Foresti F and Oliveira C (2002) Ocurrence of karyotypical mosaicism in Trichomycterus paolence (Teleostei, Trichomycteridae). Caryologia 55:283-287.

Saitoh K, Miya M, Inoue JG, Ishiguro NB and Hishida M (2003) Mitochondrial genomics of ostariophysan fishes: Perspectives on phylogeny and biogeography. J Mol Evol 56:464472.

Sato LR, Oliveira C and Foresti F (2004) Karyotype description of five species of Trichomycterus (Teleostei, Siluriformes, Trichomycteridae). Genet Mol Biol 27:45-50.

Vila I, Fuentes L and Contreras M (1999) Peces límnicos de Chile. Bol Mus Hist Nat 48:61-75.

Wosiacki WB (2002) Estudo das relações filogenéticas de Trichomycterinae (Teleostei, Siluriformes, Trichomycteridae) com uma proposta de classificação. PhD Thesis, Universidade de São Paulo, São Paulo, São Paulo, Brazil.

Associate Editor: Fausto Foresti 